\title{
Perlindungan Tenaga Kerja Anak
}

\author{
Kanyaka Prajnaparamita \\ Fakultas Hukum, Universitas Diponegoro \\ J1.Prof.Soedarto, SH Tembalang Semarang \\ anya_fh@gmail.com
}

\begin{abstract}
This study aims to determine the protection of child labor in Indonesia, especially the rules that protect child labor both in industrial areas and on entertainment such as artist child and the like. The research method used is legal research with statutory approach approach (analytical approach) which is analyzed with qualitative analysis. The results of the study show that child labor has gained enough protection from Indonesian legislation. Such protection is both at the level of the country's basic laws (contitutions) and the Law, as well as on derivative regulations issued by the central government, ministers, and local governments.
\end{abstract}

Keywords: Labor Law, Child Labor, Child Protection

\begin{abstract}
Abstrak
Penelitian ini bertujuan untuk mengetahui perlindungan tenaga kerja anak di Indonesia, khususnya aturan yang melindungi pekerja anak baik di kawasan industri maupun pada hiburan seperti artis cilik dan sejenisnya. Metode penelitian yang digunakan adalah penelitian hukum dengan pendekatan statutory approach (pendekatan perundang-undangan) yang dianalisis dengan analisis kualitatif. Hasil penelitian menunjukan bahwa tenaga kerja anak telah mendapatkan perlindungan yang cukup dari peraturan perundang-undangan di Indonesia. Perlindungan tersebut baik pada tingkat hukum dasar negara (contitutions) dan Undang Undang, maupun pada peraturan derivatif yang dikeluarkan oleh pemerintah pusat, menteri, dan pemerintahan daerah.
\end{abstract}

Kata Kunci: Hukum ketenagakerjaan, Pekerja anak, Perlindungan Anak

\section{A. Pendahuluan}

Sejak merdeka Tahun 1945, Indonesia telah mengikrarkan diri sebagai Negara Hukum, yang ingin mewujudkan rakyatnya makmur, sejahtera, dan berkeadilan. Keinginan ini tertuang di dalam Pembukaan Undang-Undang Dasar 1945 alinea IV. ${ }^{1}$ Sebagai konsekuensi negara hukum mengenai kesejahteraan, negara harus menjamin hak dan kewajiban asasi warga negara dan rakyatnya di dalam konstitusi negara, dengan pencantuman hak dan kewajiban asasi warga negara di dalam konstitusi, maka membawa konsekuensi bagi negara untuk mengakui, menghormati dan menghargai serta melakukan pemenuhan terhadap hak-hak warga negara tersebut, khususnya pemenuhan hak-hak asasi warga negara dalam kehidupan nyata. ${ }^{2}$ Selanjutnya mengenai kewajiban untuk memberikan pengakuan, pemenuhan, dan perlindungan terhadap hak asasi bagi seluruh warga negara dan rakyat ini tertuang di dalam ketentuan Pasal 28I UUD 1945, yang

\footnotetext{
${ }_{1}^{1}$ Penjelasan Umum Undang-Undang Dasar Negara Republik Indonesia Tahun 1945 butir 1

2 Netty Endrawati, Faktor Penyebab Anak Bekerja dan Upaya Pencegahannya, Jurnal Ilmu Hukum Refleksi Hukum, (Kediri : Universitas Islam Kediri, Edisi April 2011), hlm 20
} 
disebutkan bahwa perlindungan, pemajuan, penegakan, pemenuhan hak asasi manusia adalah tanggung jawab negara, terutama pemerintah.

Salah satu hak asasi yang harus dipenuhi dan dilindungi oleh negara adalah hak di bidang ketenagakerjaan, yang dalam hal ini hak untuk bekerja dan memperoleh pekerjaan, diatur di dalam ketentuan Pasal 27 ayat (2) UUD 1945, yang disebutkan bahwa tiap-tiap warga negara berhak atas pekerjaan dan penghidupan yang layak bagi kemanusiaan. Di samping itu juga dapat dilihat dalam ketentuan Pasal 28D ayat (2) UUD 1945, yang disebutkan bahwa setiap orang berhak untuk bekerja serta mendapat imbalan dan pengakuan yang adil dan layak dalam hubungan kerja. ${ }^{3}$

Pada dasarnya setiap orang yang hidup itu harus bekerja dan mempunyai pekerjaan. Hal ini dimaksudkan agar dapat memenuhi kebutuhan setiap orang yang bermacammacam. Dalam suatu pekerjaan pasti dibutuhkan suatu tenaga kerja karena adanya hubungan timbal balik di antara keduanya. Tenaga kerja merupakan salah satu faktor produksi yang penting bagi setiap negara. Tanpa adanya tenaga kerja, faktor produksi alam dan faktor produksi modal tidak dapat digunakan secara optimal. ${ }^{4}$ Tenaga kerja itu merupakan penduduk yang berada dalam usia kerja.

Secara garis besar penduduk suatu negara dibedakan menjadi dua kelompok, yaitu tenaga kerja dan bukan tenaga kerja. Penduduk tergolong tenaga kerja jika penduduk tersebut telah memasuki usia kerja. Batas usia kerja yang berlaku di Indonesia adalah berumur 15 tahun - 64 tahun. Sedangkan penduduk yang berumur kurang dari 15 tahun dan lebih dari 64 tahun, mereka tidak termasuk kelompok tenaga kerja. ${ }^{5}$ Sebagai contoh, berdasarkan data yang diperoleh dari Badan Pusat Statistik pada tahun 2016, penduduk di daerah Kabupaten Jepara berjumlah 1.205.800 orang yang terdiri dari 601.206 penduduk laki-laki dan 604.594 penduduk perempuan. Dari jumlah tersebut, penduduk yang bekerja berjumlah 583.388 orang yang terdiri dari 351.174 orang pekerja laki-laki dan 232.214 orang pekerja perempuan. Sedangkan penduduk yang menganggur berjumlah 18.800 orang yang terdiri dari 12.660 laki-laki dan 6.140 perempuan. ${ }^{6}$

Anak merupakan harta yang tak ternilai harganya, tidak hanya dilihat dari perspektif sosial, budaya, ekonomi, politik dan hukum tetapi juga dalam perspektif keberlanjutan sebuah generasi keluarga, suku, trah, maupun bangsa. Mengingat pentingnya status dan posisi anak tersebut, anak dapat bermakna sosial (kehormatan, harkat, martabat keluarga tergantung pada sikap dan perilaku anak), budaya (anak merupakan harta dan kekayaan sekaligus merupakan lambang kesuburan sebuah keluarga), politik (anak adalah penerus trah atau suku masyarakat tertentu), ekonomi (pada sementara anggapan masyarakat jawa khusunya ada adagium "banyak anak, banyak rejeki”, sehingga 'mengkaryakan' atau mempekerjakan anak dapat menambah penghasilan atau rejeki), hukum (anak mempunyai kedudukan strategis di depan hukum). ${ }^{7}$

\footnotetext{
${ }^{3}$ Loc.cit

${ }^{4}$ Zona Siswa, Pengertian dan Klasifikasi Ketenagakerjaan, diakses dari http://www.zonasiswa.com, pada tanggal 18 Januari 2018 pukul 09:00

${ }^{5}$ Dananggana Satriatama, Buruh dan Tenaga Kerja, diakses dari https://danangstr.wordpress.com/2016/11/07/buruhdan-tenaga-kerja/, pada tanggal 18 Januari 2018 pukul 10:00

${ }^{6}$ Badan Pusat Statistik Kabupaten Jepara

${ }^{7}$ Emei Dwinanarhati Setiamandani, Perlindungan Hukum Bagi Pekerja Anak dan Upaya Penanggulangannya, Jurnal Reformasi, (Malang: Universitas Muhammadiyah Malang, 2012), hlm 1
} 
Pada hakekatnya anak tidak boleh bekerja karena waktu mereka selayaknya dimanfaatkan untuk belajar, bermain, bergembira, berada dalam suasana damai, mendapatkan kesempatan dan fasilitas untuk mencapai cita-citanya sesuai dengan perkembangan fisik, psikologi, intelektual dan sosialnya. Namun pada kenyataannya banyak anak-anak di bawah usia 18 tahun yang telah terlibat aktif dalam kegiatan ekonomi, menjadi pekerja anak antara lain di sektor industri dengan alasan tekanan ekonomi yang dialami orang tuanya ataupun faktor lainnya. ${ }^{8}$

Salah satu masalah anak yang harus memperoleh perhatian khusus, adalah isu pekerja anak (child labor). Isu ini telah mengglobal karena begitu banyak anak-anak di seluruh dunia yang sudah bekerja pada usia sekolah. Pada kenyataannya isu pekerja anak bukan sekedar isu anak menjalankan pekerjaan dengan memperoleh upah, akan tetapi lekat sekali dengan eksploitasi, pekerjaan berbahaya, terhambatnya akses pendidikan dan menghambat perkembangan fisik, psikis dan sosial anak. Bahkan dalam kasus dan bentuk tertentu pekerja anak telah masuk sebagai kualifikasi anak-anak yang bekerja pada situasi yang paling tidak bisa ditolelir (the intolerable form of child labor). ${ }^{9}$

Walaupun ada seperangkat peraturan yang melindungi pekerja anak, tetapi kecenderungan kualitas permasalahan pekerja anak dari tahun ke tahun mengalami perkembangan kompleksitas menuju bentuk-bentuk pekerjaan terburuk yang eksploitatif dan membahayakan pertumbuhan dan perkembangan fisik, mental, moral, sosial dan intelektual anak. Jenis pekerjaan terburuk semakin marak ditemukan, seperti anak yang dilacurkan, anak yang diperdagangkan, anak bekerja dipertambangan, dan lain-lain. ${ }^{10}$

Misalnya pada beberapa industri mebel di Kabupaten Jepara yang telah memiliki beberapa pekerja dewasa merasa masih kurang atau tidak cukup untuk membantu proses produksi dan pembungkusan (packing) dan juga karena pekerja dewasa dianggap sudah memiliki pengalaman dalam dunia kerja dan pastinya sudah memiliki skill tertentu dan jika hanya diberi pekerjaan mudah seperti membungkus barang dan atau sekedar mengecat barang akan merugikan perusahaan, maka dipilihlah pekerja anak yang memang kebanyakan belum memiliki skill dalam bidang furniture. Jadi pekerjaan mudah seperti mengecat barang atau sekedar membungkus barang untuk persiapan pengiriman akan lebih efektif dengan biaya murah. Dengan umur anak sekitar 14 sampai 15 tahun dianggap sudah cukup kuat juga untuk melakukan pekerjaan berat seperti mengangkat barang ke dalam container jika barang sudah siap untuk dikirim.

Namun masih terdapat juga industri-industri di Kabupaten Jepara yang mempekerjakan pekerja anak dengan tidak memberikan hak-hak yang wajib didapatkannya. Perekrutan tenaga kerja seharusnya tidak melibatkan anak-anak dalam menjalankan usahanya, karena undang-undang sudah mengatur pelanggaran mempekerjakan anak di bawah umur yang terdapat pada Undang-Undang Nomor 13 Tahun 2003 Tentang Ketenagakerjaan, dan apabila dilanggar pengusaha akan dikenakan sanksi sesuai dengan Undang-Undang yang berlaku.

\footnotetext{
${ }^{8}$ Kutipan dari Tesis Eka Tjahjanto, Implementasi Peraturan Perundang-undangan Ketenagakerjaan Sebagai Upaya Perlindungan Hukum Terhadap Eksploitasi Pekerja Anak, hlm 13.

${ }^{9}$ Loc.cit

${ }^{10}$ Fifik Wiryani, Perlindungan Pekerja Anak, Pusat Studi Kajian Wanita, (Malang: UMM Press, 2003), hlm 3
} 
Berdasarkan uraian di atas, maka penulis mencoba melakukan penelitian untuk melakukan analisis mengenai hal-hal yang terjadi pada pekerja/buruh anak tentang perlindungan hukum terhadap hak-hak pekerja/buruh anak pada industri mebel di Kabupaten Jepara yang dihubungkan dengan Undang-Undang Nomor 13 Tahun 2003 Tentang Ketenagakerjaan.

\section{Rumusan Masalah}

Berdasarkan pada latar belakang di atas, beberapa pokok permasalahan yang akan dibahas dalam tulisan ini adalah ini, yaitu Bagaimana perlindungan hukum terhadap pekerja/buruh anak dan Faktor-faktor apa sajakah yang melatarbelakangi banyaknya pekerja/buruh anak.

\section{B. Pembahasan}

\section{Tinjauan Umum Tentang Tenaga Kerja dan Pekerja/Buruh}

Dalam Undang-Undang yang baru tentang ketenagakerjaan yaitu Undang-Undang Nomor 13 Tahun 2003 tentang Tenaga Kerja memberikan pengertian tentang tenaga kerja yang terdapat dalam Pasal 1 angka 2 bahwa tenaga kerja yaitu setiap orang yang mampu melakukan pekerjaan guna menghasilkan barang dan/atau jasa baik untuk memenuhi kebutuhan sendiri maupun untuk masyarakat. Pengertian tenaga kerja dalam UndangUndang Nomor 13 Tahun 2003 tentang Tenaga Kerja tersebut telah menyempurnakan pengertian tentang tenaga kerja dalam Undang-Undang Nomor 14 Tahun 1969 tentang Ketentuan Pokok Ketenagakerjaan. ${ }^{11}$

Pengertian tentang tenaga kerja yang dikemukakan oleh Dr. Payaman Simanjuntak memiliki pengertian yang lebih luas dari pekerja/buruh. Pengertian tenaga kerja disini mencakup tenaga kerja/buruh yang sedang terkait dalam suatu hubungan kerja dan tenaga kerja yang belum bekerja. Sedangkan pengertian dari pekerja/buruh adalah setiap orang yang bekerja dengan menerima upah atau imbalan dalam bentuk lain. Dengan kata lain, pekerja atau buruh adalah tenaga kerja yang sedang dalam ikatan hubungan kerja. ${ }^{12}$

Seperti dikatakan oleh S.Mulyadi bahwa tenaga kerja (man power) pada dasarnya adalah penduduk dalam usia kerja (berusia 15-64 tahun) atau jumlah seluruh penduduk dalam suatu negara yang dapat memproduksi barang dan jasa jika ada permintaan terhadap tenaga mereka, dan jika mereka mau berpartisipasi dalam aktivitas tersebut. ${ }^{13}$

Menurut Suparmoko dan Icuk Ranggabawono, tenaga kerja ialah penduduk yang sudah memasuki usia kerja dan mempunyai pekerjaan, yang sedang mencari pekerjaan, dan yang melakukan suatu kegiatan lain seperti sekolah, kuliah dan mengurus rumah tangga. ${ }^{14}$

Sedangkan menurut Alam. S, tenaga kerja adalah penduduk yang berusia 15 tahun ke atas untuk negara-negara berkembang seperti Indonesia. Sedangkan di negara-negara maju, tenaga kerja yaitu penduduk yang berumur antara 15 hingga 64 tahun. ${ }^{15}$

\footnotetext{
${ }^{11}$ Sendjun H. Manulang, Pokok-Pokok Hukum Ketenagakerjaan di Indonesia, (Jakarta: Rhineka Cipta, 2001), hlm 3

${ }^{12}$ Hardijan Rusli, Hukum Ketenagakerjaan, (Jakarta: Ghalia Indonesia, 2003), hlm 12-13

${ }^{13}$ S.Mulyadi, Ekonomi Sumber Daya Manusia dalam Perspektif Pembangunan, (Jakarta: Rajawali Pers, 2012), hlm 59

${ }^{14}$ Diakses dari http://www.sumberpengertian.co/pengertian-tenaga-kerja

${ }^{15}$ Loc.cit
} 


\section{Pengertian Pekerja/Buruh}

Menurut Undang-Undang Nomor 13 Tahun 2003 Pasal 1 angka 3 Tentang Ketenagakerjaan, pekerja/buruh adalah setiap orang yang bekerja dengan menerima upah atau imbalan dalam bentuk lain.

Menururt Maimun, Pekerja adalah setiap orang bekerja dengan menerima upah dan imbalan dalam bentuk lain. Dalam definisi tersebut terdapat dua unsur yaitu orang yang bekerja dan menerima upah atau imbalan dalam bentuk lain. ${ }^{16}$

Menurut Kamus Besar Bahasa Indonesia, Buruh adalah orang yang bekerja untuk orang lain dengan mendapat upah. Sedangkan karyawan adalah orang yang bekerja pada suatu lembaga (kantor, perusahaan, dan sebagainya) dengan mendapat gaji (upah). ${ }^{17}$

Sedangkan pengertian menurut Abdul Rahmad Budiono, Buruh adalah setiap orang yang bekerja dengan menerima upah atau imbalan dalam bentuk lain. Dengan dipadankannya istilah pekerja dengan buruh merupakan kompromi setelah dalam kurun waktu yang amat panjang dua istilah tersebut bertarung untuk dapat diterima oleh masyarakat. $^{18}$

Dalam perkembangan hukum perburuhan di Indonesia, istilah buruh diupayakan untuk diganti dengan istilah pekerja, karena istilah buruh kurang sesuai dengan kepribadian bangsa, buruh lebih cenderung menunjuk pada golongan yang selalu ditekan dan berada di bawah pihak lain yakni majikan. Istilah pekerja secara yuridis baru ditemukan dalam Undang-Undang Nomor 25 Tahun 1997 tentang Ketenagakerjaan. ${ }^{19}$

\section{Pengertian Pekerja/Buruh Anak}

\section{a. Anak}

Berdasarkan Undang-Undang Nomor 13 Tahun 2003 Pasal 1 angka 26 yang menyebutkan bahwa pengertian anak adalah setiap orang yang berumur di bawah 18 (delapan belas) tahun.

Menurut Undang-Undang Nomor 35 Tahun 2014 Pasal 1 angka 1 tentang Perlindungan Anak disebutkan bahwa pengertian anak adalah seseorang yang belum berusia 18 (delapan belas) tahun, termasuk anak yang masih dalam kandungan. ${ }^{20}$

Dijelaskan dalam Pasal 330 Kitab Undang-Undang Hukum Perdata, mengatakan orang belum dewasa adalah mereka yang belum mencapai umur 21 tahun dan tidak lebih dahulu telah kawin. Jadi anak adalah setiap orang yang belum berusia 21 tahun dan belum menikah. Seandainya seorang anak telah menikah sebelum umur 21 tahun kemudian bercerai atau ditinggal mati oleh suaminya sebelum genap umur 21 tahun, maka ia tetap dianggap sebagai orang yang telah dewasa bukan anak-anak. ${ }^{21}$

\footnotetext{
${ }^{16}$ Maimun, Hukum Ketenagakerjaan Suatu Pengantar, (Jakarta: PT Pradnya Paramita, 2003), hlm 13

${ }^{17}$ Kamus Besar Bahasa Indonesia

${ }^{18}$ Abdul Rahmad Budiono, Hukum Perburuhan, (Jakarta: PT.Indeks, Cetakan ke-I, 2009), hlm 5

${ }^{19}$ Lalu Husni, Pengantar Hukum Ketenagakerjaan Indonesia, (Jakarta: PT Raja Grafindo Persada, Cetakan ke-II, 2001), hlm 22

${ }^{20}$ Undang-Undang Nomor 35 Tahun 2014 Tentang Perlindungan Anak Pasal 1

${ }^{21}$ Subekti dan Tjitrosudibio, Kitab Undang-Undang Hukum Perdata, (Jakarta : PT. Pradnya Paramita, 2002), hlm 90
} 
Pengertian tersebut berbeda dengan pengertian yang terdapat pada UndangUndang Nomor 4 tahun 1979 dimana menyebutkan bahwa anak adalah seseorang yang belum mencapai usia 21 tahun dan belum pernah kawin. ${ }^{22}$

Sedangkan menurut Konvensi PBB tahun 1989 tentang Hak-Hak Anak dan Konvensi ILO Nomor 182 tahun 1999 tentang Pelarangan dan Tindakan Segera Penghapusan Bentuk-bentuk Pekerjaan Terburuk untuk Anak, Anak adalah seorang individu yang berusia di bawah 18 tahun. $^{23}$

Sedangkan menurut R.A. Kosnan, Anak-anak yaitu manusia muda dalam umur, muda dalam jiwa dan perjalanan hidupnya karena mudah terpengaruh untuk keadaan sekitarnya. $^{24}$

\section{b. Pekerja/Buruh Anak}

Pengertian pekerja anak adalah anak-anak yang berusia 4 hingga 18 tahun yang bekerja diberbagai bidang pekerjaan yang berkelanjutan dan menyita hampir seluruh waktu mereka sebagai anak sehingga tidak dapat bersekolah seperti anak-anak lainnya secara normal. ${ }^{25}$

Definisi Pekerja Anak menurut ILO/ IPEC adalah anak yang bekerja pada semua jenis pekerjaan yang membahayakan atau mengganggu fisik, mental, intelektual dan moral. Konsep pekerja anak didasarkan pada Konvensi ILO Nomor 138 mengenai usia minimum untuk diperbolehkan bekerja yang menggambarkan definisi internasional yang paling komprehensif tentang usia minimum untuk diperbolehkan bekerja, mengacu secara tidak langsung pada "kegiatan ekonomi". Konvensi ILO menetapkan kisaran usia minimum di bawah ini dimana anak-anak tidak boleh bekerja. Usia minimum menurut Konvensi ILO Nomor 138 untuk negara-negara dimana perekonomian dan fasilitas pendidikan kurang berkembang adalah semua anak berusia 5 - 11 tahun yang melakukan kegiatan-kegiatan ekonomi adalah pekerja anak sehingga perlu dihapuskan. Anak-anak usia 12 - 14 tahun yang bekerja dianggap sebagai pekerja anak, kecuali jika mereka melakukan tugas ringan. Sedangkan usia sampai dengan 18 tahun tidak diperkenankan bekerja pada pekerjaan yang termasuk berbahaya. ${ }^{26}$

\section{Tinjauan Umum Tentang Eksploitasi Anak}

\section{a. Pengertian Eksploitasi Anak}

Menurut Undang-Undang Nomor 21 Tahun 2007 Pasal 1 angka 7 Tentang Tindak Pidana Perdagangan Orang menyebutkan bahwa eksploitasi adalah tindakan dengan atau tanpa persetujuan korban yang meliputi tetapi tidak terbatas pada pelacuran, kerja atau pelayanan paksa, perbudakan atau praktik serupa perbudakan, penindasan, pemerasan, pemanfaatan fisik, seksual, organ reproduksi, atau secara melawan hukum memindahkan atau mentransplantasi organ dan/atau jaringan tubuh atau memanfaatkan tenaga atau

\footnotetext{
${ }^{22}$ Undang-Undang Nomor 4 tahun 1979 Tentang Kesejahteraan Anak Pasal 1

${ }^{23}$ Konvensi PBB tahun 1989 tentang Hak-hak Anak dan Konvensi ILO Nomor 182 tahun 1999 tentang Pelarangan dan Tindakan Segera Penghapusan Bentuk-bentuk Pekerjaan Terburuk untuk Anak

${ }^{24}$ R.A. Koesnan, Susunan Pidana dalam Negara Sosialis Indonesia, (Bandung :Sumur, 2005), hlm 113

${ }^{25}$ Muhammad Saifur Rohman, Makalah Pekerja Anak, (Probolinggo: Universitas Panca Marga, 2013), hlm 6

26 Hari Harjanto Setiawan \& Adhani Wardianti, Pekerja anak, diakses dari https://rumahkita2010.wordpress.com/2010/03/08/pekerja-anak/, pada tanggal 8 Januari 2018 pukul 17:43 WIB
} 
kemampuan seseorang oleh pihak lain untuk mendapatkan keuntungan baik materiil maupun immateriil.

Menururt Surayin dalam Buku Kamus Umum Bahasa Indonesia, Eksploitasi adalah pengusahaan, pendayagunaan, pemanfaatan untuk keuntungan sendiri, pengisapan, dan pemerasan (tenaga orang). ${ }^{27}$

Eksploitasi (Inggris: exploitation) adalah politik pemanfaatan yang secara sewenangwenang atau terlalu berlebihan terhadap sesuatu subyek eksploitasi hanya untuk kepentingan ekonomi semata-mata tanpa mempertimbangkan rasa kepatutan, keadilan serta kompensasi kesejahteraan. ${ }^{28}$

\section{b. Macam-Macam Eksploitasi}

Di Indonesia banyak sekali terjadi eksploitasi terhadap anak, bahkan seringkali dilakukan oleh orang-orang terdekat si anak yang tak lain adalah keluarga atau orang tua anak itu sendiri. Di bawah ini beberapa macam eksploitasi yang dapat terjadi kepada anak, yaitu: ${ }^{29}$

\section{Eksploitasi Fisik}

Eksploitasi fisik adalah penyalahgunaan tenaga anak untuk dipekerjakan demi keuntungan orang tuanya atau orang lain seperti menyuruh anak bekerja dan menjuruskan anak pada pekerjaan-pekerjaan yang seharusnya belum dijalaninya. Dalam hal ini, anak-anak dipaksa bekerja menggunakan segenap tenaganya dan juga mengancam jiwanya. Tekanan fisik yang berat dapat menghambat perawakan atau fisik anak-anak hingga 30\% karena mereka mengeluarkan cadangan stamina yang harus bertahan hingga dewasa. Oleh sebab itu, anak-anak sering mengalami cedera fisik yang bisa diakibatkan oleh pukulan, cambukan, luka bakar, lecet dan goresan, atau memar dengan berbagai tingkat penyembuhan, fraktur, luka pada mulut, bibir, rahang, dan mata. ${ }^{30}$

Eksploitasi Sosial

Eksploitasi sosial adalah segala sesuatu yang dapat menyebabkan terhambatnya perkembangan emosional anak. ${ }^{31}$ Hal ini dapat berupa kata-kata yang mengancam atau menakut-nakuti anak, penghinaan anak, penolakan anak, menarik diri atau menghindari anak, tidak memperdulikan perasaan anak, perilaku negatif pada anak, mengeluarkan kata-kata yang tidak baik untuk perkembangan emosi anak, memberikan hukuman yang ekstrim pada anak seperti memasukkan anak pada kamar gelap, mengurung anak di kamar mandi, dan mengikat anak. ${ }^{32}$

Pada sektor jasa, terutama hotel dan hiburan, anak-anak direkrut berdasarkan penampilan, dan berkemampuan untuk menjalin hubungan dengan orang lain. Mereka harus melayani para pelanggan yang kebanyakan orang dewasa, sehingga

\footnotetext{
${ }^{27}$ Surayin, Kamus Umum Bahasa Indonesia, (Bandung: CV.Yrama Widiya, cetakan ke-IV, 2007) hlm 129

${ }^{28}$ Diakses dari http://id.wikipedia.org/wiki/Eksploitasi, pada tanggal 2 Februari 2018 jam 20:32.

${ }^{29}$ Meivy R. Tumengkol , Jurnal Holistik, 2016, hlm 4-6

30 Jurnal Equilibrium Pendidikan Sosiologi, Volume IV No. 1 Mei 2016, diakses dari https://media.neliti.com/media/publications/69241-ID-eksploitasi-pekerja-anak-pemulung.pdf pada tanggal 8 Februari 2018

${ }^{31}$ P Joko subagyo, Metode Penelitian dalam Teori dan Praktek, (Jakarta: Rhineka Cipta, cetakan ke-I, 1999), hlm 63

${ }^{32}$ Ibid, hlm 47
} 
berpeluang untuk mengalami tekanan batin karena mengalami rayuan-rayuan seksual. $^{33}$

\section{Eksploitasi Seksual}

Eksploitasi seksual adalah keterlibatan anak dalam kegiatan seksual yang tidak dipahaminya. Eksploitasi seksual dapat berupa perlakuan tidak senonoh dari orang lain, kegiatan yang menjurus pada pornografi, perkataan-perkataan porno, membuat anak malu, menelanjangi anak, prostitusi anak, perbuatan cabul dan persetubuhan pada anak-anak yang dilakukan orang lain dengan tanpa tanggung jawab, tingkatan mendorong atau memaksa anak terlibat dalam kegiatan seksual yang melanggar hukum seperti dilibatkan pada kegiatan prostitusi. ${ }^{34}$

Eksploitasi Ekonomi

Eksploitasi ekonomi (eksploitasi komersial) adalah penggunaan anak untuk bekerja dan kegiatan lainnya demi kebutuhan orang tuanya atau orang lain seperti menyuruh anak bekerja secara berlebihan, menjerumuskan anak kepada dunia prostitusi untuk kepentingan ekonomi. ${ }^{35}$

\section{c. Faktor Penyebab Timbulnya Eksploitasi Anak}

\section{Kemiskinan}

Pendapat para ahli ilmu sosial tentang masalah kemiskinan, khususnya perihal sebab mengapa munculnya kemiskinan dalam suatu masyarakat berbeda-beda. Sekelompok ahli ilmu sosial melihat munculnya kemiskinan dalam satu masyarakat berkaitan dengan budaya yang hidup dalam suatu masyarakat. Dalam konteks pandangan seperti ini maka kemiskinan sering dikaitkan dengan rendahnya etos kerja anggota masyarakat, atau dengan bahasa yang lebih populer sebab-sebab kemiskinan terkait dengan rajin atau tidaknya seseorang dalam bekerja/mengolah sumber-sumber alam yang tersedia. Apabila orang rajin bekerja, dapat dipastikan orang tersebut akan hidup dengan kecukupan. Selain rajin, orang itu memiliki sifat hemat. Manusia yang memiliki etos kerja tinggi dan sifat hemat pasti akan hidup lebih dari kecukupan. ${ }^{36}$

Kemiskinan juga diartikan sebagai suatu keadaan dimana seseorang tidak sanggup memelihara diri sendiri sesuai dengan taraf kehidupan kelompok dan juga tidak mampu memanfaatkan tenaga, mental, maupun. Kemiskinan dapat diukur dengan membandingkan tingkat pendapatan seseorang atau rumah tangga dengan tingkat pendapatan yang diperlukan untuk memenuhi kebutuhan minimumnya. Dari sisi ini kemiskinan dapat dibedakan menjadi dua, yaitu kemiskinan absolut dan kemiskinan relatif. ${ }^{37}$

Seseorang dikatakan miskin secara absolut apabila tingkat pendapatannya lebih rendah daripada garis kemiskinan absolut yang ditetapkan, atau dengan kata lain jumlah pendapatannya tidak cukup untuk memenuhi kebutuhan minimum yang

\footnotetext{
${ }^{33}$ Hadari Nawawi, Metode Penelitian Bidang Sosial, (Yogyakarta: Gajah Mada Unversity Press, 1998), hlm 31

34 Mieke Diah Anjar Yanit, dkk., Model Sistem Monitoring dan Pelaporan Anak dan Perempuan Korban Kekerasan, Bapenas, Propinsi Jateng, 2006, hlm 9-11

${ }^{35}$ Loc.cit

${ }^{36}$ Bagong Suyanto, Masalah Sosial Anak, (Jakarta: Kencana, 2010), hlm 115

${ }^{37}$ Zainal Asikin, Dasar-Dasar Hukum Perburuhan, (Jakarta: PT Raja Grafindo Persada, 2004), hlm 16
} 
dicerminkan oleh garis kemiskinan absolut tersebut. ${ }^{38}$ Tingkat pendapatan minimum merupakan pembatas antara keadaan yang disebut miskin dan tidak miskin, atau sering disebut dengan garis kemiskinan. Garis Kemiskinan adalah kemampuan seseorang atau keluarga memenuhi kebutuhan hidup standar pada suatu waktu dan lokasi tertentu untuk melangsungkan hidupnya. Standar hidup dimaksud mencerminkan tingkat kebutuhan minimal untuk memenuhi pangan, sandang, pemukiman, pendidikan, dan kesehatan. ${ }^{39}$

2. Pengaruh Lingkungan Sosial

Dalam konteks lingkungan sosial di masyarakat Indonesia, anak yang bekerja dianggap sebagai wahana positif untuk memperkenalkan disiplin serta menanamkan etos kerja pada anak. Hal ini sudah menjadi bagian dari budaya dan tata kehidupan keluarga Indonesia. Banyak orang merasa bahwa bekerja merupakan hal positif bagi perkembangan anak sehingga sejak dini anak diikutsertakan dalam proses kerja. ${ }^{40}$

Pada beberapa komunitas tertentu, sejak kecil anak-anak sudah dididik untuk bekerja, misalnya di sektor pertanian, perikanan, industri kerajinan, nelayan, dan lain-lain. Namun, pekerjaan yang dilakukan tidaklah berbahaya bagi kondisi kesehatan anak secara fisik, mental, dan sosial sehingga tidak melanggar hak mereka sebagai anak. Proses ini seakan menjadi wadah bagi anak untuk belajar bekerja. ${ }^{41}$ Sayangnya dalam perkembangan selanjutnya, proses belajar bekerja tidak lagi berkembang sebagaimana mestinya. Berbagai faktor menyebabkan anak terpaksa bekerja dalam situasi dan kondisi kerja yang tidak layak dan berbahaya bagi perkembangannya.

Kelangkaan fasilitas pendidikan, rendahnya kualitas pendidikan dasar, rendahnya kesadaran masyarakat (khususnya orang tua) terhadap pentingnya pendidikan, kurikulum pendidikan yang kurang akomodatif terhadap tantangan kerja di masa depan, dan mahalnya biaya pendidikan menyebabkan pendidikan dipandang sebagai suatu hal yang elit dan mewah terutama di kalangan masyarakat miskin. Kondisi ini mendorong anak untuk memasuki dunia kerja. Beberapa hasil penelitian menunjukkan bahwa anak yang bekerja sebagian besar berpendidikan rendah ${ }^{42}$

\section{Pengaturan Tentang Pekerja/Buruh Anak di Indonesia}

Hak anak adalah bagian dari hak asasi manusia yang wajib dijamin, dilindungi dan dipenuhi oleh orang tua, keluarga, masyarakat, negara, pemerintah, dan pemerintah daerah (Pasal 1 ayat (12) Undang-Undang Nomor 35 Tahun 2014). Anak-anak, seperti halnya orang dewasa, mempunyai hak atas hak asasi dasar manusia. Namun, karena kebutuhan mereka, hak-hak anak perlu diperhatikan dan diperlakuan secara khusus. Konvensi hakhak anak dirancang untuk menegakkan dan menjaga hak-hak anak. Hak-hak anak tersebut termasuk: (1) Hak untuk kelangsungan hidup, (2) Hak-hak untuk tumbuh kembang, (3) Hak-hak untuk dilindungi, dan (4) Hak-hak untuk berpartisipasi. Dalam koridor tersebut, terhadap anak tidak dibenarkan adanya perbuatan yang dapat menghambat pertumbuhan

\footnotetext{
${ }^{38}$ Ibid, hlm 21

${ }^{39}$ Ibid, hlm 23

${ }^{40}$ Hadari Nawawi, Metode Penelitian Bidang Sosial, (Yogyakarta: Gajah Mada University Press, 1998), hlm 49

${ }^{41}$ Ibid, halaman 50

${ }^{42}$ Dewan Redaksi Ensiklopedia Islam, Ensiklopedia Islam 1, (Jakarta: Ichtiar Baru Van Hoeve, 1997), hlm 141
} 
dan perkembangan. Seorang anak yang tidak dapat diasuh dengan baik oleh orang tuanya dapat mengakibatkan pembatalan hak asuh orang tua. ${ }^{43}$

Bagi para pekerja anak pun sesungguhnya mereka akan memilih untuk bersekolah maupun bermain bersama teman-teman daripada menjalani hidup sebagai pekerja anak. Berkaitan dengan hal tersebut adapun hak-hak yang dimiliki oleh anak-anak yaitu seperti yang diatur dalam Undang-Undang Nomor 4 Tahun 1979 Bab II Pasal 2 sampai dengan 9, mengatur hak-hak anak atas kesejahteraan, diperkuat dalam Undang-undang Nomor 35 Tahun 2014 dalam Bab III Pasal 4 sampai 18 adalah sebagai berikut :

a. Hak Atas Kesejahteraan, Perawatan, Asuhan dan Bimbingan.

Anak berhak atas kesejahteraan, perawatan, asuhan dan bimbingan berdasarkan kasih sayang baik dalam keluarganya maupun di dalam asuhan khusus untuk tumbuh dan berkembang dengan wajar. Dimaksud dengan asuhan, adalah berbagai upaya yang dilakukan kepada anak yang tidak mempunyai orang tua dan terlantar, anak terlantar dan anak yang mengalami masalah kelainan yang bersifat sementara sebagai pengganti orang tua atau keluarga agar dapat tumbuh dan berkembang dengan wajar, baik secara rohani, jasmani maupun sosial (Pasal 1 angka 32 Peraturan Pemerintah Nomor 2 Tahun 1988).

b. Hak Atas Pelayanan

Anak berhak atas pelayanan untuk mengembangkan kemampuan dan kehidupan sosialnya sesuai dengan kebudayaan dan kepribadian bangsa untuk menjadi warga negara yang baik dan berguna (Pasal 2 ayat (2) Undang-Undang Nomor 4 Tahun 1979).

c. Hak Atas Perlindungan Lingkungan Hidup

Anak berhak atas perlindungan terhadap lingkungan hidup yang dapat membahayakan atau menghambat pertumbuhan dan perkembangannya dengan wajar (Pasal 2 ayat (4) Undang-undang Nomor 4 Tahun 1979).

d. Hak Mendapat Pertolongan Pertama

Dalam keadaan yang membahayakan, anaklah yang pertama-tama berhak mendapat pertolongan, bantuan dan perlindungan (Pasal 3 Undang-undang Nomor 4 Tahun 1979).

e. Hak Memperoleh Asuhan

Anak yang tidak mempunyai orang tua berhak memperoleh asuhan oleh negara, atau orang, atau badan lain (Pasal 4 ayat (1) Undang-undang Nomor 4 Tahun 1979). Dengan demikian anak yang tidak mempunyai orang tua itu dapat tumbuh dan berkembang secara wajar baik jasmani, rohani maupun sosial.

f. Hak Memperoleh Bantuan

Anak yang tidak mampu berhak memperoleh bantuan, agar dalam lingkungan keluarganya dapat tumbuh dan berkembang dengan wajar (Pasal 5 ayat (1) Undangundang Nomor 4 Tahun 1979). Menurut Peraturan Pemerintah Nomor 2 Tahun 1988, bantuan itu bersifat tidak tetap dan diberikan dalam jangka waktu tertentu kepada anak yang tidak mampu sebagaimana diatur dalam Pasal 1 ayat (4).

\footnotetext{
${ }^{43}$ M. Ghufron, Pekerja Anak Bermasalah, (Semarang: Puspa Swara, 2001), hlm 33
} 
Selain hak-hak yang sudah dijelaskan di atas, terdapat juga hak-hak lain yang seharusnya didapatkan oleh pekerja anak sebagaimana yang telah diatur dalam UndangUndang Nomor 13 Tahun 2003 Tentang Ketenagakerjaan yaitu meliputi :

a. Hak Mendapatkan Gaji yang Layak

Pekerja/buruh anak harus mendapatkan gaji yang sesuai dengan peraturan perundang-undangan yang berlaku, sehingga pengusaha dilarang membayar lebih rendah dari ketentuan upah minimum yang telah ditetapkan pemerintah setempat sebagaimana yang telah diatur dalam Pasal 90 ayat (1) Undang-Undang Nomor 13 Tahun 2003. Apabila pengusaha memperjanjikan pembayaran upah yang lebih rendah dari upah minimum, maka kesepakatan tersebut batal demi hukum yang diatur dalam Pasal 91 ayat (2) Undang-Undang Nomor 13 Tahun 2003.

b. Hak Mendapatkan Waktu Kerja yang Sesuai

Pasal 69 dalam Undang-Undang Nomor 13 Tahun 2003 telah memberikan ketentuan pengecualian yang membolehkannya dengan syarat berusia 13 sampai dengan 15 tahun, waktu kerja tidak boleh lebih dari 3 jam, dilakukan pada siang hari, tidak mengganggu waktu sekolahnya, ada izin tertulis dari orang tua atau walinya, ada perjanjian kerja dengan orangtua atau walinya, dan diberikan upah sesuai aturan perundang-undangan. Apabila pengusaha melanggar Pasal 69 dalam UndangUndang Nomor 13 Tahun 2003 maka dapat dikenakan sanksi pidana sebagaimana diatur di dalam Pasal 185.

c. Hak Mendapatkan Waktu Istirahat dan Cuti yang Cukup

Dalam Pasal 79 ayat (1) telah dijelaskan bahwa Pengusaha wajib memberi waktu istirahat dan cuti kepada pekerja/buruh. Selain hal itu, setiap pekerja wajib memperoleh sedikitnya 12 hari untuk cuti tahunan, namun dengan kondisi pekerja tersebut harus sudah bekerja minimal 1 tahun atau 12 bulan lamanya di suatu perusahaan. Pada Pasal 79 ayat (2) dalam Undang-Undang Nomor 13 tahun 2003 tentang ketenagakerjaan, pekerja yang berhak mendapat cuti tahunan 12 hari adalah pekerja yang sudah bekerja minimum 1 tahun di perusahaan.

d. Hak Mendapatkan Pendidikan

Menurut Pasal 9 Undang-Undang Nomor 35 Tahun 2014 Tentang Perubahan Atas Undang-Undang Nomor 23 Tahun 2002 Tentang Perlindungan Anak telah dijelaskan bahwa setiap anak berhak memperoleh pendidikan dan pengajaran dalam rangka pengembangan pribadinya dan tingkat kecerdasannya sesuai dengan minat dan bakatnya. Selain itu Setiap anak juga berhak mendapatkan perlindungan di satuan pendidikan dari kejahatan seksual dan kekerasan yang dilakukan oleh pendidik, tenaga kependidikan, sesama peserta didik, dan/atau pihak lain.

Selain itu, dalam Pasal 69 ayat (2) huruf d Undang-Undang Nomor 13 Tahun 2003 telah dijelaskan pula bahwa pengusaha yang mempekerjakan anak pada pekerjaan ringan harus dilakukan pada siang hari dan tidak mengganggu waktu sekolah

e. Hak Mendapatkan Keselamatan dan Kesehatan Kerja

Berdasarkan Undang-Undang Nomor 13 Tahun 2003 telah diatur mengenai segala hal yang berhubungan dengan ketenagakerjaan mulai dari upah kerja, jam kerja, hak maternal, cuti sampai dengan keselamatan dan kesehatan kerja. Berdasarkan pada Pasal 74 di dalam Undang-Undang ini telah disebutkan secara 
jelas bahwa siapapun dilarang mempekerjakan dan melibatkan anak pada pekerjaanpekerjaan terburuk yang dapat membahayakan kesehatan, keselamatan, atau moral anak.

\section{Bentuk-Bentuk Pekerjaan Terburuk bagi Anak (BPTA)}

Indonesia melalui Undang-Undang Nomor 1 Tahun 2000, telah meratifikasi Konvensi ILO Nomor 182 mengenai Pelarangan dan Tindakan Segera Penghapusan Bentuk-bentuk Pekerjaan Terburuk untuk Anak (BPTA). Konvensi yang ditetapkan secara aklamasi pada tahun 1999 ini memberikan rincian tentang BPTA di mana anak di bawah 18 tahun tidak boleh terlibat di dalamnya. Konvensi juga menuntut Negara agar mengambil langkah-langkah segera dan efektif untuk memastikan ditetapkannya pelarangan dan penghapusan bentuk-bentuk terburuk pekerjaan terburuk untuk anak. Dalam konvensi dan undang-undang tersebut di atas, istilah "bentuk-bentuk pekerjaan terburuk untuk anak" mengandung pengertian:

a. Segala bentuk perbudakan atau praktek-praktek yang mirip dengan perbudakan, seperti penjualan dan perdagangan anak, perbudakan akibat hutang dan penghambaan dan kerja paksa atau kerja wajib, termasuk rekrutmen wajib atau rekrutmen paksa, terhadap anak-anak untuk digunakan dalam konflik bersenjata.

b. Pemanfaatan, penyediaan, penawaran anak untuk pelacuran, produksi pornografi, dan pertunjukan-pertunjukan porno.

c. Pemanfaatan, penyediaan atau penawaran anak untuk kegiatan terlarang, khususnya untuk produksi dan perdagangan obat-obatan sebagaimana diatur dalam pernjanjian internasional yang relevan.

d. Pekerjaan yang sifat atau keadaan tempat pekerjaan itu dilakukan dapat membahayakan kesehatan, keselamatan, atau moral anak-anak.

Sebagai pelaksanaan Ratifikasi ILO Nomor 182 tersebut di atas, Pemerintah telah menyusun Rencana Aksi Nasional Penghapusan BPTA melalui Keputusan Presiden Nomor 59 Tahun 2002 yang secara khusus memunculkan beberapa contoh Bentuk Pekerjaan Terburuk untuk Anak, seperti:

1) Anak-anak yang dilacurkan.

2) Anak-anak yang bekerja di pertambangan.

3) Anak-anak yang bekerja sebagai penyelam mutiara.

4) Anak-anak yang bekerja di sektor konstruksi.

5) Anak-anak yang bekerja di jermal.

6) Anak-anak yang bekerja sebagai pemulung sampah

7) Anak-anak yang dilibatkan dalam produksi dan kegiatan yang menggunakan bahan-bahan peledak.

8) Anak-anak yang bekerja di jalan.

9) Anak-anak yang bekerja sebagai pembantu rumah tangga.

10) Anak-anak yang bekerja di industri rumah tangga.

11) Anak-anak yang bekerja di sektor perkebunan.

12) Anak-anak yang bekerja pada penebangan, pengolahan dan pengangkutan kayu.

13) Anak-anak yang bekerja pada industri dan kegiatan yang menggunakan bahan kimia berbahaya 
Dari ke-13 (tiga belas) Bentuk-bentuk Pekerjaan Terburuk terhadap Anak (BPTA) tersebut, maka pemerintah Indonesia menaruh perhatian pada empat sektor khusus yang paling diprioritaskan untuk Rencana Aksi Nasional Pengapusan Bentuk-bentuk Pekerjaan Terburuk terhadap Anak (RAN PBPTA) tahap II yaitu:

1) Pekerja Rumah Tangga Anak (PRTA)

2) Perdagangan Anak untuk Eksploitasi Seksual Komersial

3) Pekerjaan di sektor Pertanian/Perkebunan

4) Anak jalanan yang beresiko diperdagangkan dan terlibat dalam peredaran narkoba.

\section{Prinsip-Prinsip Perlindungan Anak}

Prinsip-Prinsip Perlindungan Anak adalah : ${ }^{44}$

a. Anak tidak dapat berjuang sendiri

Salah satu prinsip yang digunakan dalam perlindungan anak yaitu anak adalah modal utama kelangsungan hidup manusia, bangsa dan keluarga, untuk itu hakhaknya harus dilindungi. Anak tidak dapat melindungi sendiri hak-haknya, banyak pihak yang mempengaruh kehidpannya. Negara dan masyarakat berkepentingan untuk mengusahakan perlindungan hak-hak anak.

b. Kepentingan terbaik anak (the best interest of the child) :

Agar perlindungan anak dapat diselenggarakan dengan baik, dianut prinsip yang menyatakan bahwa kepentingan terbaik anak harus dipandang sebagai of paramount importence (memperoleh prioritas tertinggi) dalam setiap keputusan yang menyangkut anak. Tanpa prinsip ini perjuangan untuk melindungi anak akan mengalami banyak batu sandungan. Prinsip the best interest of the child digunakan karena dalam banyak hal anak "korban", disebabkan ketidaktahuan anak, karena usia perkembangannya. Jika prinsip ini diabaikan, maka masyarakat menciptakan monster-monster yang lebih buruk dikemudian hari.

c. Rancangan daur kehidupan (life-circle approach) :

Perlindungan anak mengacu pada pemahaman bahwa perlindungan anak harus dimulai sejak dini dan terus-menerus. Janin yang berada dalam kandungan perlu dilindungi dengan gizi, termasuk yodium dan kalsium yang baik melalui ibunya. Jika ia telah lahir, maka diperlukan air susu ibu (ASI) dan pelayanan kesehatan primer dengan memberikan pelayanan imunisasi dan lain-lain, sehingga anak terbebas dari berbagai kemungkinan cacat dan penyakit. Masa-masa pra sekolah dan sekolah, diperlukan keluarga, lembaga pendidikan, dan lembaga sosial/keagamaan yang bermutu. Anak memperoleh kesempatan belajar yang baik, waktu istirahat dan bermain yang cukup, dan ikut menentukan nasibnya sendiri. Pada saat anak sudah berumur 15-18 tahun, ia memasuki masa transisi ke dalam dunia dewasa. Periode ini penuh risiko karena secara kultural, seseorang akan dianggap dewasa dan secara fisik memang telah cukup sempurna untuk menjalankan fungsi reproduksinya. Pengetahuan yang benar tentang reproduksi dan perlindungan dari berbagai diskriminasi dan perlakuan salah, dapat memasuki perannya sebagai orang dewasa

\footnotetext{
44 Maidin Gultom, Perlindungan Hukum Terhadap Anak dan Perempuan, (Bandung: Refika Aditama, 2013), halaman 71
} 
yang berbudi dan bertanggung jawab. Perlindungan hak-hak mendasar bagi pra dewasa juga diperlukan agar generasi penerus, tetap bermutu. Orang tua yang terdidik mementingkan sekolah anak-anak mereka. Orang tua yang sehat jasmani dan rohaninya, selalu menjaga tingkah laku kebutuhan, baik fisik maupun emosional anak-anak mereka.

d. Lintas Sektoral :

Nasib anak tergantung dari berbagai faktor, baik yang makro maupun mikro, yang langsung maupun tidak langsung. Kemiskinan, perencanaan kota dan segala penggusuran, sistem pendidikan yang menekankan hafalan dan bahan-bahan yang tidak relevan, komunitas yang penuh dengan ketidakadilan, dan sebagainya tidak dapat ditangani oleh sektor, terlebih keluarga atau anak itu sendiri. Perlindungan terhadap anak adalah perjuangan yang membutuhkan sumbangan semua orang di semua tingkatan.

\section{Bentuk Upaya Perlindungan Terhadap Anak}

Upaya-upaya dalam rangka perlindungan hukum tersebut dilakukan dengan melakukan ratifikasinya terhadap Konvensi Hak Anak yang diwujudkan ke dalam Undang-Undang Nomor 35 tahun 2014 tentang Perlindungan Anak, yang dengan jelas menegaskan kewajiban pemerintah untuk melakukan perlindungan secara khusus terhadap anak dalam situasi darurat. Peraturan ini secara eksplisit menyadari bahwa pentingnya upaya negara untuk memberikan perlindungan kepada anak-anak. Sebagaimana terdapat dalam Pasal 20 yang menyebutkan bahwa negara, pemerintah, pemerintah daerah, masyarakat, keluarga dan orang tua atau Wali berkewajiban dan bertanggung jawab terhadap penyelenggaraan perlindungan anak.

Sementara pada Pasal 22 dalam Undang-Undang yang sama diatur sebagai berikut yang menyebutkan bahwa negara, pemerintah dan pemerintah daerah berkewajiban dan bertanggung jawab memberikan dukungan sarana, prasarana dan ketersediaan sumber daya manusia dalam penyelenggaraan Perlindungan Anak. Dengan demikian negara atau pemerintah berkewajiban untuk melakukan perlindungan terhadap anak dan bertanggung jawab memberikan sarana dan prasarana dalam penyelenggaraan perlindungan tersebut.

Sanksi-sanksi pidana mengenai perlindungan hukum terhadap anak yang dicantumkan dalam beberapa Pasal antara lain:

a. Pasal 77

"Setiap orang yang melanggar ketentuan sebagaimana dimaksud dalam Pasal 76A (dilarang memperlakukan Anak secara diskriminatif yang mengakibatkan Anak mengalami kerugian, baik materiil maupun moril sehingga menghambat fungsi sosialnya atau memperlakukan Anak Penyandang Disabilitas secara diskriminatif.) dipidana dengan pidana penjara paling lama 5 (lima) tahun dan/atau denda paling banyak Rp100.000.000,00 (seratus juta rupiah)."

b. Pasal 78

"Setiap orang yang mengetahui dan sengaja membiarkan anak dalam situasi darurat, anak yang behadapan dengan hukum, anak dari kelompok minoritas terisolasi, anak yang tereksploitasi secara ekonomi dan/atau seksual, anak yang diperdagangkan, anak yang menjadi korban penyalahgunaan narkotika, alkohol, psikotropika, dan zat 
adiktif lainnya (napza), anak korban penculikan, anak korban perdagangan, anak korban kekerasan, padahal anak tersebut memerlukan pertolongan dan harus dibantu, dipidana dengan pidana penjara paling lama 5 (lima) tahun dan/atau denda paling banyak Rp. 100.000.000 (seratus juta rupiah)"

c. Pasal 80

Ayat (1): "Setiap Orang yang melanggar ketentuan sebagaimana dimaksud dalam Pasal 76C (dilarang menempatkan, membiarkan, melakukan, menyuruh melakukan, atau turut serta melakukan Kekerasan terhadap Anak), dipidana dengan pidana penjara paling lama 3 (tiga) tahun 6 (enam) bulan dan/atau denda paling banyak Rp72.000.000,00 (tujuh puluh dua juta rupiah).".

Ayat (2): "Dalam hal Anak sebagaimana dimaksud pada ayat (1) luka berat, maka pelaku dipidana dengan pidana penjara paling lama 5 (lima) tahun dan/atau denda paling banyak Rp100.000.000,00 (seratus juta rupiah).”.

Ayat (3): "Dalam hal Anak sebagaimana dimaksud pada ayat (2) mati, maka pelaku dipidana dengan pidana penjara paling lama 15 (lima belas) tahun dan/atau denda paling banyak Rp3.000.000.000,00 (tiga miliar rupiah).”.

Ayat (4): "Pidana ditambah sepertiga dari ketentuan sebagaimana dimaksud pada ayat (1), ayat (2), dan ayat (3) apabila yang melakukan penganiayaan tersebut orang tuanya.".

d. Pasal 81

"Setiap orang yang dengan sengaja melakukan kekerasan atau ancaman kekerasan memaksa anak melakukan persetubuhan dengannya atau dengan orang lain, dipidana dengan pidana penjara paling lama 15 (lima belas) tahun dan paling singkat 3 (tiga) tahun dan denda paling banyak Rp. 300.000 .000 (tiga ratus juta rupiah) dan paling sedikit Rp. 60.000 .000 (enam puluh juta rupiah)".

e. Pasal 82 Ayat (1)

"Setiap orang yang melanggar ketentuan sebagaimana dimaksud dalam Pasal 76E (dilarang melakukan Kekerasan atau ancaman Kekerasan, memaksa, melakukan tipu muslihat, melakukan serangkaian kebohongan, atau membujuk Anak untuk melakukan atau membiarkan dilakukan perbuatan cabul.) dipidana dengan pidana penjara paling singkat 5 (lima) tahun dan paling lama 15 (lima belas) tahun dan denda paling banyak Rp5.000.000.000,00 (lima miliar rupiah)".

f. Pasal 83

"Setiap orang yang melanggar ketentuan sebagaimana dimaksud dalam Pasal 76F (dilarang menempatkan, membiarkan, melakukan, menyuruh melakukan, atau turut serta melakukan penculikan, penjualan, dan/atau perdagangan Anak.) dipidana dengan pidana penjara paling singkat 3 (tiga) tahun dan paling lama 15 (lima belas) tahun dan denda paling sedikit Rp60.000.000,00 (enam puluh juta rupiah) dan paling banyak Rp300.000.000,00 (tiga ratus juta rupiah)".

g. Pasal 88

"Setiap Orang yang melanggar ketentuan sebagaimana dimaksud dalam Pasal 76I (dilarang menempatkan, membiarkan, melakukan, menyuruh melakukan, atau turut 
serta melakukan eksploitasi secara ekonomi dan/atau seksual terhadap Anak.), dipidana dengan pidana penjara paling lama 10 (sepuluh) tahun dan/atau denda paling banyak Rp200.000.000,00 (dua ratus juta rupiah)."

Pasal-Pasal yang berkaitan dengan sanksi tersebut memberikan gambaran bahwa pemerintah menunjukkan keseriusan dan komitmennya untuk benar-benar melakukan perlindungan terhadap anak. Atau dengan kata lain dapat diartikan bahwa, perlindungan anak secara yuridis sudah tertuang dalam Undang-Undang Nomor 35 Tahun 2014 yang juga mengatur tentang pemberian sanksi terhadap hal-hal yang menyangkut pada kerugian yang dialamai oleh anak, seperti kekerasan, perdagangan dan lain-lain, dengan bentuk sanksi yang berupa tahanan maupun dendan yang cukup besar.

\section{Simpulan}

Berdasarkan pembahasan yang telah diuraikan maka dapat disimpulkan bahwa Pertama, Pelaksanaan perlindungan hukum terhadap hak-hak pekerja/buruh anak di Indonesia belum sepenuhnya sesuai dengan peraturan perundang-undangan yang berlaku, yaitu seperti:

a. Hak untuk mendapatkan gaji/upah yang layak (Pasal 90 ayat (1) Undang-Undang Nomor 13 Tahun 2003).

b. Hak untuk mendapatkan jam kerja yang sesuai (Pasal 69 dalam Undang-Undang Nomor 13 Tahun 2003).

c. Hak untuk mendapatkan waktu istirahat dan cuti yang cukup (Pasal 79 ayat (1) Undang-Undang Nomor 13 Tahun 2003).

d. Hak untuk mendapatkan pendidikan (Pasal 9 Undang-Undang Nomor 35 Tahun 2014).

e. Hak untuk mendapatkan Keselamatan dan Kesehatan Kerja (Pasal 74 UndangUndang Nomor 13 Tahun 2003).

Faktor yang melatarbelakangi banyaknya pekerja/buruh anak tidak terlidnungi adalah terdiri dari dua faktor, yaitu faktor internal dan faktor eksternal. Faktor Internal, terdiri dari : Faktor ekonomi, Faktor pendidikan, Faktor kemauan sendiri, Faktor kebiasaan. Sedangkan Faktor Eksternal, terdiri dari: Faktor lingkungan sekitar, Faktor Hubungan Keluarga. 


\section{Daftar Pustaka}

Adam Smith (diedit oleh Edwin Cannan), An Inquiry into the Nature and Causes of the Wealth of Nations, New York : The Modern Library, 1985

Agustin Asikin, Tina Noorjaya (editor), Pajak, Citra, dan Bebannya, Bina Rena Pariwara, Jakarta, 1990

Diaz Priantara, Pemeriksaan dan Penyidikan Pajak, Penerbit Djambatan, Jakarta, 2000

Ernest Baker, The Politics of Aristotle, Oxford University Press, London-New York, 1984

Frans Magnis Suseno, Etika Politik, Prinsip-prinsip Moral Dasar Kenegaraan Modern, Pustaka Gramedia, Jakarta, 1991

Glenn T. Jenkins \& Ganghadar P., Public Finance in Open Economics, Harvard International Tax Program, Harvard Institute for International Development, 1997

Goedhart, C. (Terjemahan : Ratmoko), Garis-garis Besar Ilmu Keuangan Negara, Penerbit Djambatan, Jakarta, 1973

Guritno Mangkoesoebroto, Ekonomi Publik, BP FE UGM, Yogyakarta, 1993

Hector S. de Leon, Fundamental of Taxation, Rex Book Store, Manila, Philipinnes, 1993

Hill Hal, Transformasi Ekonomi Indonesia Sejak 1966, Tiara Wacana Yogyakarta, 1996

\section{Makalah dan Artikel}

Anggito Abimanyu, Reformasi Perpajakan Perlu Dukungan Masyarakat, Artikel Harian Kompas tanggal 23 Nopember 2008

Anwar Nasution , Perkembangan Perekonomian Indonesia 1978-1991, Dampak Jangka Pendek dan Implikasi Jangka Panjang, Prisma No. 9 Tahun 1991

Dadut Priyambodo, Paksa Badan Atau Krisis Lagi?, Harian Kompas Tanggal 11 Oktober 2000

Hussein Kartasasmita, Pemeriksaan Pajak dan Reformasi, Majalah Hukum Bisnis, Vol. 3 Tahun 1998

, Reformasi Perpajakan Perihal BPSP dan Penagihan Dengan Surat Paksa, Majalah Hukum Bisnis, Vol. 4 Tahun 1998 